\title{
Osmotic Concentration of Gooseberry Fruits - The Influence of Temperature, Time and Pretreatment Methods on Mass Transfer and Total Polyphenol and Organic Acid Content
}

\author{
Anna Kucner ${ }^{1}$, Robert Klewicki ${ }^{1 *}$, Michał Sójka ${ }^{1}$ and Elżbieta Klewicka ${ }^{2}$ \\ ${ }^{1}$ Institute of Chemical Technology of Food, Lodz University of Technology, 4/10 Stefanowskiego Street, \\ PL-90-924 Lodz, Poland \\ ${ }^{2}$ Institute of Fermentation Technology and Microbiology, Lodz University of Technology, \\ 171/173 Wolczanska Street, PL-90-530 Lodz, Poland \\ Received: March 13, 2013 \\ Accepted: July 31, 2014
}

\begin{abstract}
Summary
The objective of the study is to assess the influence of temperature, time and enzymatic pretreatment on the osmotic concentration of gooseberry fruits (cultivar Biały Triumf). The fruits were osmotically concentrated in a sucrose solution at $65{ }^{\circ}$ Brix and 40 to $70{ }^{\circ} \mathrm{C}$ for 5 to $240 \mathrm{~min}$. Two experimental procedures were employed. In the first procedure, prior to concentration the fruits were immersed in the solution containing lipolytic enzymes, and then in the solution containing pectinolytic enzymes. In the second procedure, pectinolytic enzymes were added to the sucrose solution. The kinetics of the osmotic concentration was studied based on the changes in dry matter content, water loss, and solid gain. Higher temperature and longer process time led to higher values of the mentioned parameters. After $1 \mathrm{~h}$ of concentration at $40^{\circ} \mathrm{C}$, dry matter content was $13.9 \%$, while at 70 ${ }^{\circ} \mathrm{C}$ it was $20.4 \%$. The use of pectinolytic enzymes during osmotic concentration resulted in higher effectiveness of the process. After $2 \mathrm{~h}$ of concentration with the use of pectinolytic enzymes, solid gain was seven times higher than that in the control sample. Enzymatic treatment with lipase and pectinase before concentration also increased solid gain during osmotic concentration (up to twelve times after $2 \mathrm{~h}$ at $40^{\circ} \mathrm{C}$ ). The lower processing temperature, the higher retention of phenolic compounds in fruits was observed. The retention of phenolics was the highest at $40{ }^{\circ} \mathrm{C}(92.2 \%$ at $2 \mathrm{~h})$. Among organic acids (malic, shikimic and citric), the highest retention was exhibited by citric acid; at $1 \mathrm{~h}$ of concentration, its fraction in the obtained fruit syrup content was from 95.9 to $83.1 \%$ as compared to the starting material.
\end{abstract}

Key words: gooseberry, osmotic concentration, total polyphenols, organic acids

\section{Introduction}

The gooseberry (Ribes uva-crispa L.) is a fruit-bearing shrub belonging to the family Grossulariaceae (1). According to FAOSTAT data (2), the leading gooseberry producers in Europe are, in descending order, Russia, Germany and Poland. Gooseberry fruits are a natural source of organic acids (3). Stewart (4) reports that these fruits contain citric acid (11 to $14 \mathrm{mg}$ per $100 \mathrm{~g}$ of fresh mass (fm)), malic acid (10 to $13 \mathrm{mg}$ per $100 \mathrm{~g}$ of $\mathrm{fm}$ ), and shikimic acid (1 to $2 \mathrm{mg}$ per $100 \mathrm{~g}$ of $\mathrm{fm}$ ). Organic acids are responsible for the characteristic tart and sour taste of the fruits (5). Due to their nature, these compounds have found many applications in the food industry. They are widely used in the manufacture of juices and beverages as $\mathrm{pH}$ regulators and preservatives $(6,7)$. Some authors have reported that citric acid inhibits Listeria monocytogenes bacteria. It has also been found that malic acid is a more effec- 
tive inhibitor of thermophilic bacteria than acetic or lactic acids (7). Thanks to their chelating properties, organic acids may reduce human susceptibility to diseases of civilization (8). Literature data suggest that compounds such as citric, tartaric, malic, succinic, fumaric, glutaric and ketoglutaric acids may decrease the risk of stroke and Alzheimer's disease if consumed on a regular basis (9).

Phenolic compounds are important antioxidant components of gooseberry fruits, with a total content of approx. $190 \mathrm{mg}$ per $100 \mathrm{~g}$ of $\mathrm{fm}$ (10). The main constituent group of phenolic compounds in gooseberry fruits consists of flavonols, including quercetin, myricetin, and kaempferol. The following phenolic acids have been identified in gooseberry fruits: caffeic, coumaric, hydroxybenzoic and ellagic (11). It has been shown that consumption of products rich in polyphenolic compounds may reduce the risk of cardiac and cardiovascular disorders by antioxidant action towards low-density lipoproteins (LDLs), delaying the process of arteriosclerosis (12).

In vitro studies have revealed a potentially beneficial effect of gooseberry fruit extracts in the treatment of type 2 diabetes and hypertension (13). Furthermore, methanol extracts of gooseberry fruits have been shown to have antifungal properties against Candida glabrata and Candida lipolytica strains (14).

Freshly harvested gooseberries have a short shelf-life. Long or inadequate storage may lead to deteriorated taste, texture, and appearance. In a quest to meet consumer demands, the food industry seeks such preservation methods that would ensure products of the highest possible quality. A good example here is osmotic dehydration. It is a processing technique which enables a longer shelf-life and increased utility of the product with a relatively small loss of valuable nutrients (15). The process includes the immersion of material having cellular structure in a hypertonic solution. Osmotic dehydration involves two major types of mass transfer, i.e. diffusion of water from the fruits to the hypertonic solution and a simultaneous transport of the osmoactive substance into the fruits. Due to the low selectivity of the cell membrane, low molecular mass substances such as sugars, organic acids, minerals, and vitamins are leached into the hypertonic solution $(16,17)$. The amount of nutrients decreases to a various degree, which mostly depends on the type of dehydrated material and the conditions of the process. The use of suboptimal parameters of osmotic dehydration may not only adversely affect the texture of the fruits, but also decrease the nutritional value of the final product $(18,19)$.

Osmotic dehydration of gooseberries is difficult due to the thick skin of the fruits. Over the past years, much attention has been devoted to methods that would increase the effectiveness of osmotic dehydration, especially in the case of such material; these include exposure of the material to ultrasound (20), high intensity electrical field pulses (21), centrifugal force (22), and dehydration under vacuum (23).

The objective of the present study is to examine the influence of temperature, time and enzymatic pretreatment on the kinetics of osmotic concentration as well as on the content of phenolic compounds and organic acids in gooseberry fruits.

\section{Material and Methods}

\section{Chemicals}

Potassium phosphate was obtained from Chempur (Piekary Śląskie, Poland) and sodium carbonate from P.P.H. (Gliwice, Poland). Commercial grade sucrose was purchased from a local store. Ultrapure water (Millipore, Billerica, MA, USA) was used to prepare all the solutions. The Folin-Ciocalteu phenol reagent was purchased from POCh S.A. (Gliwice, Poland). Malic, citric, and shikimic acid standards as well as metaphosphoric acid were purchased from Sigma-Aldrich (Steinheim, Germany). The enzymes Pectinex ${ }^{\circledR}$ YieldMASH and Palatase ${ }^{\circledR} 2000$ L were obtained from Novozymes (Bagsværd, Denmark).

\section{Material}

Green gooseberry fruits (Ribes uva-crispa L. cv. Biały Triumf) were harvested at a plantation located in Dmosin, Poland, in July 2011. The fruits were stored in a freezer at $-20{ }^{\circ} \mathrm{C}$ and kept at approx. $22{ }^{\circ} \mathrm{C}$ for $15 \mathrm{~min}$ after taking out from the freezer prior to processing. The osmotic solution was obtained by mixing commercial grade sucrose with distilled water to obtain the concentration of $65^{\circ}$ Brix.

\section{Osmotic concentration without pretreatment}

Osmotic concentration of gooseberry fruits was conducted under dynamic conditions (shaking at 200 cycles per min). First, $(20.0 \pm 0.5) \mathrm{g}$ of samples (this amount guaranteed the homogeneousness of samples in individual containers; all fruits in a container constituted one sample for analysis) were placed in plastic containers and sucrose solution at $65^{\circ}$ Brix was added. Solution temperature was $40,50,60$ or $70^{\circ} \mathrm{C}$ and dehydration time was from 5 to 240 min (for each temperature and experimental time two containers were taken, samples were analyzed simultaneously, thus the results are the average values of two analyses). The fruit to syrup ratio was 1:4 (by mass). After completing the dehydration process, the samples were rinsed with distilled water three times and dried on absorbent paper.

\section{Osmotic concentration with pectinolytic enzymes}

As described above, $(20.0 \pm 0.5) \mathrm{g}$ of samples were placed in plastic containers, and then sucrose solution at $65^{\circ}$ Brix and $0.06 \mathrm{~mL}$ of the pectinolytic enzyme Pectinex ${ }^{\circledR}$ YieldMASH (enzyme activity of $46000 \mathrm{PGU} / \mathrm{mL}$ ) were added. Osmotic concentration was conducted at $40{ }^{\circ} \mathrm{C}$ for 30 to $240 \mathrm{~min}$ with continuous shaking (200 cycles per min). For each experimental time, two containers were taken, two samples were analyzed simultaneously, thus the results are the average of two analyses.

\section{Osmotic concentration following pretreatment with lipolytic and pectinolytic enzymes}

First, $(240.0 \pm 5.0) \mathrm{g}$ of frozen fruits were placed in a beaker, to which $1 \mathrm{~L}$ of distilled water and $0.09 \mathrm{~mL}$ of the lipolytic preparation (enzyme activity of 20000 PGU/mL) were added. Prior to the addition of the enzyme, water $\mathrm{pH}$ was adjusted to 7 . After $30 \mathrm{~min}$, water was decanted and 
the fruits were rinsed with distilled water three times. Subsequently, $1 \mathrm{~L}$ of water and $4.86 \mathrm{~mL}$ of the pectinolytic preparation (enzyme activity of $46000 \mathrm{PGU} / \mathrm{mL}$ ) were added. Subsequently, $(20.0 \pm 0.5) \mathrm{g}$ of samples were placed in plastic containers and sucrose solution at $65^{\circ}$ Brix was added. The pretreated fruits were osmotically concentrated at $40{ }^{\circ} \mathrm{C}$ for 30 to $240 \mathrm{~min}$. For each experimental time, two containers were taken, two samples were analyzed simultaneously, thus the results are the average of two analyses.

\section{Preparation of samples for analysis}

Following osmotic concentration, the samples were ground under liquid nitrogen in an A11B mill (IKA, Staufen, Germany).

\section{Determination of dry matter content}

Dry matter content was determined as follows: $(2.0 \pm 0.5) \mathrm{g}$ of samples were placed in glass vessels containing $(10.0 \pm 1.0) \mathrm{g}$ of dried sand. Subsequently, the samples were dried in a vacuum dryer $\left(0.92 \mathrm{~kg} / \mathrm{cm}^{2}\right)$ at $(60 \pm 2){ }^{\circ} \mathrm{C}$ for $10 \mathrm{~h}$. Next, the samples were cooled down in a desiccator and weighed.

\section{Calculation of osmotic concentration parameters}

Osmotic parameters were calculated as follows:

$$
\begin{gathered}
\text { Water loss }=\frac{m_{0}\left(1-m_{\mathrm{s}_{\mathrm{o}}}\right)-m_{\mathrm{k}}\left(1-m_{\mathrm{s}_{\mathrm{k}}}\right)}{m_{0} \cdot m_{\mathrm{s}_{\mathrm{o}}}} /(\mathrm{g} / \mathrm{g}) \\
\text { Solid gain }=\frac{m_{\mathrm{k}} \cdot m_{\mathrm{s}_{\mathrm{o}}}-m_{\mathrm{k}} \cdot m_{\mathrm{s}_{\mathrm{k}}}}{m_{0} \cdot m_{\mathrm{s}_{\mathrm{o}}}} /(\mathrm{g} / \mathrm{g})
\end{gathered}
$$

where $m_{0}$ and $m_{\mathrm{k}}$ are the mass (in $\mathrm{g}$ ) of the sample before and after osmotic concentration, and $m_{\mathrm{so}}$ and $m_{\mathrm{sk}}$ are the initial and final mass of solids in the sample ( $g$ of dry matter per $g$ of sample) before and after osmotic treatment. The mass transfer kinetics of osmotic concentration of gooseberry fruits was determined on the basis of water loss expressed as $g$ of $\mathrm{H}_{2} \mathrm{O}$ per $\mathrm{g}$ of initial dry matter and solid gain expressed as $g$ of dry matter per $g$ of initial dry matter (24).

\section{Phenolic extraction}

First, $(2.0 \pm 0.5) \mathrm{g}$ of each sample were weighed into a plastic test tube and $5 \mathrm{~mL}$ of $\mathrm{MeOH} / \mathrm{H}_{2} \mathrm{O} / \mathrm{HCOOH}$ solution (50:48:2) were added. The sample was vortexed and sonicated (vibration frequency of $(35 \pm 5) \mathrm{kHz}$; InterSonic, Olsztyn, Poland) for $15 \mathrm{~min}$. Then, the sample was centrifuged at $20000 \times g$ for $5 \mathrm{~min}$ (using a centrifuge from Mechanika Precyzyjna, Warsaw, Poland). The supernatant was collected in a $25-\mathrm{mL}$ volumetric flask. The material was extracted five more times. The flasks were filled to a desired volume with the extraction solution. The obtained extracts were used for the determination of total phenolic content.

\section{Determination of total phenolic content}

Total soluble phenolics in methanol extracts were determined using the Folin-Ciocalteu reagent according to the method of Singleton and Rossi (25), with (-)-epicatechin as a standard. Subsequently, $0.1 \mathrm{~mL}$ of the extract was added to a $25-\mathrm{mL}$ volumetric flask, $0.25 \mathrm{~mL}$ of the Folin-Ciocalteu phenol reagent was added to the mixture, and the flask was shaken. After $5 \mathrm{~min}, 2.5 \mathrm{~mL}$ of $20 \% \mathrm{Na}_{2} \mathrm{CO}_{3}$ solution were added with subsequent mixing. The solution was then immediately diluted to a volume of $25 \mathrm{~mL}$ with $\mathrm{H}_{2} \mathrm{O}$ and mixed thoroughly. After incubation for 60 min at $20{ }^{\circ} \mathrm{C}$, the absorbance relative to that of the blank was measured at $720 \mathrm{~nm}$ using a spectrophotometer (Metertech SP-880, Taipei, Taiwan). A calibration curve was prepared using (-)-epicatechin as a standard and the results are expressed as (-)-epicatechin equivalents per 100 $\mathrm{g}$ of initial dry matter.

\section{Organic acid extraction}

Samples of $(1.0 \pm 0.2) \mathrm{g}$ were extracted three times with $3 \mathrm{~mL}$ of $2 \%$ aqueous solution of $m-\mathrm{H}_{3} \mathrm{PO}_{4}$ (by volume). All samples were placed in an ultrasonic cleaner (vibration frequency of $(35 \pm 5) \mathrm{kHz}$; InterSonic) for $15 \mathrm{~min}$. Next, the samples were centrifuged in a centrifuge (Mechanika Precyzyjna), and the supernatant was decanted into a $10-\mathrm{mL}$ flask. Following the extraction, the flasks were filled to a desired volume with the reagent used for extraction. Samples prepared in this way were purified in columns with cation-exchange resin. The columns were conditioned with $10 \mathrm{~mL}$ of $3 \% \mathrm{HCl}$ and $10 \mathrm{~mL}^{\circ} \mathrm{H}_{2} \mathrm{O}$, and then $5 \mathrm{~mL}$ of samples were placed in them. The first $2 \mathrm{~mL}$ were discarded, and the rest was collected into 2-millilitre Eppendorf tubes. Following centrifugation in a GmCLab Gilson centrifuge $(2690 \times g)$, the samples were subjected to HPLC analysis.

\section{RP-HPLC analysis of organic acids}

Qualitative and quantitative analysis of organic acids was performed with a Knauer HPLC (Berlin, Germany) chromatograph equipped with an UV diode-array detector (DAD) and a Phenomenex Security Guard Cartridge system $(4.0 \mathrm{~mm} \times 3.0 \mathrm{~mm}$; Torrance, CA, USA). Compounds were separated on $150.0 \mathrm{~mm} \times 4.6 \mathrm{~mm}$ Phenomenex Gemini 5 u C18 $110 \mathrm{~A}$ columns at $20^{\circ} \mathrm{C}$. UV detection was performed at $210 \mathrm{~nm}$. The mobile phase was $1 \%$ phosphate buffer and the following parameters were used: $\mathrm{pH}=2.5$, flow rate $1 \mathrm{~mL} / \mathrm{min}$, and injection volume $20 \mu \mathrm{L}$. Chromatographic peaks in the samples were identified by comparing their retention times and UV spectra with the reference standards. Quantitative results were given as standard equivalents.

\section{Microscopy of gooseberry skin}

Photographs were taken with a Nikon Eclipse Ci H600L (Nikon, Tokyo, Japan) microscope (total magnification 400×) operated with NIS-Elements Advanced Research v. 3.0 software (Nikon).

\section{Statistical analysis}

The results were analyzed statistically using one-way ANOVA and Duncan's multiple range test at $p<0.05$ with the Statistica v. 6.1 software (StatSoft, Tulsa, OK, USA). 


\section{Results and Discussion}

\section{Dry matter content, water loss and solid gain}

Data presented in Fig. 1a indicate that dry matter gain during osmotic concentration of gooseberry fruits largely depends on temperature and time. The highest dry matter mass fraction (38.7 \%) was found in fruits dehydrated at $70{ }^{\circ} \mathrm{C}$ for $180 \mathrm{~min}$. At 50 and $60^{\circ} \mathrm{C}$, dry matter mass fraction after $1 \mathrm{~h}$ of dehydration was 13.8 and $16.0 \%$, respectively, while after $4 \mathrm{~h}$ it increased by 47 and $26.5 \%$, respectively. At $40{ }^{\circ} \mathrm{C}$, no statistically significant differences in dry matter content were found between initial and dehydrated material.

Water loss analysis (Fig. 1b) proves that the application of higher temperatures enables a reduction in the time of gooseberry dehydration. After 180 min of osmotic concentration at $50^{\circ} \mathrm{C}$, water loss from the fruits was $1.1 \mathrm{~g}$ of $\mathrm{H}_{2} \mathrm{O}$ per $\mathrm{g}$ of initial dry matter, while at $70^{\circ} \mathrm{C}$ the same effect was achieved after $30 \mathrm{~min}$. A high water loss of 3.57 $\mathrm{g}$ of $\mathrm{H}_{2} \mathrm{O}$ per $\mathrm{g}$ of initial dry matter was observed at $70^{\circ} \mathrm{C}$ after $180 \mathrm{~min}$.

Increased temperature led to faster migration of the osmotic substance to the dehydrated tissue, which is corroborated by the results shown in Fig. 1c. For example, after $120 \mathrm{~min}$ of dehydration at $50{ }^{\circ} \mathrm{C}$, solid gain was 0.09 $\mathrm{g}$ of dry matter per $\mathrm{g}$ of initial dry matter, while at $60^{\circ} \mathrm{C}$ it was $0.80 \mathrm{~g}$ of dry matter per $\mathrm{g}$ of initial dry matter. It should be stressed that irrespective of the used temperature, solid gain was smaller than water loss. After $60 \mathrm{~min}$ of dehydration at $60^{\circ} \mathrm{C}$, solid gain was $0.69 \mathrm{~g}$ of dry matter per $\mathrm{g}$ of initial dry matter, while water loss was $1.2 \mathrm{~g}$ of $\mathrm{H}_{2} \mathrm{O}$ per $\mathrm{g}$ of initial dry matter. This means that the increase in dry matter content (Fig. 1a) for particular osmotic concentration settings was caused to a greater extent by water loss than by transfer of the osmoactive substance (sucrose) into the fruits.

Many authors have sought to establish the influence of temperature and time on the osmotic dehydration of a variety of fruits and vegetables (however, it is emphasized that the phenomenon of mass transfer during osmotic dehydration depends on many factors, such as the type of raw material and process parameters, including time, concentration of the osmotic solution, and the fruit to syrup ratio) $(15,17,26)$. Our results show that dehydration at 70 ${ }^{\circ} \mathrm{C}$ leads to faster mass transfer, but with time some adverse structural changes affect the fruits (that is why the process was stopped after $180 \mathrm{~min}$ at $70^{\circ} \mathrm{C}$ ). Lewicki and Porzecka-Pawlak (27) reported that dehydration of apple cubes for $3 \mathrm{~h}$ compromised the rigidity of the surface layers and caused the formation of small intercellular spaces. According to literature data (19), high temperatures result in the swelling and plasticizing of cell membranes. This enables faster diffusion of water from the product and better mass transfer near the surface of the fruits, which is also helped by the dilution of the osmotic solution and its decreased viscosity. We suppose that the slow mass transfer at 40 and $50{ }^{\circ} \mathrm{C}$ may have also been due to the low porosity of the epidermal layer of gooseberry fruits. This layer formed an effective barrier against the penetration of the osmoactive substance and the loss of water from the
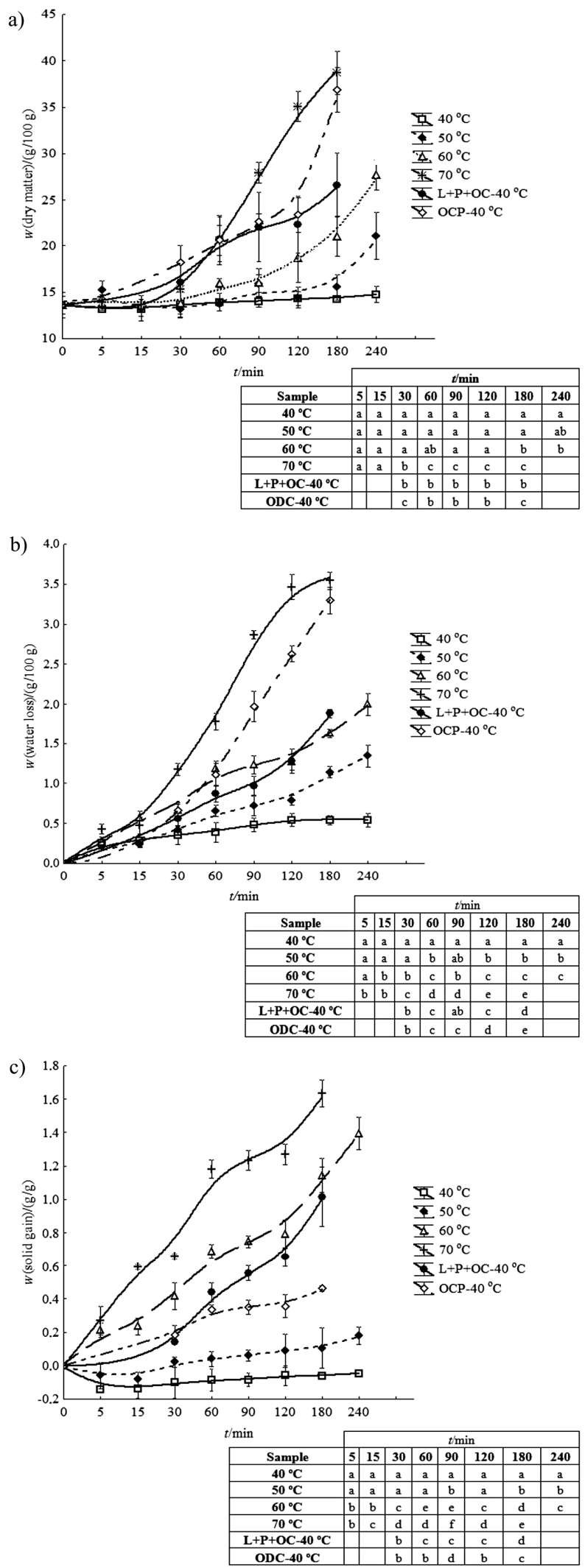

Fig. 1. Changes in: a) dry matter content, b) water loss, and c) solid gain during osmotic concentration of gooseberry fruits at $40,50,60$ and $70^{\circ} \mathrm{C}$, pretreated by immersion in a water bath containing lipase and pectinase $\left(\mathrm{L}+\mathrm{P}+\mathrm{OC}-40^{\circ} \mathrm{C}\right)$ or dehydrated with the addition of pectinolytic enzymes (ODC $\left.-40{ }^{\circ} \mathrm{C}\right)$. In table: the same letter for a given process time means no significant differences (95\% confidence level) 
fruits during concentration. The use of enzymatic preparations led to more effective osmotic concentration at 40 ${ }^{\circ} \mathrm{C}$ (Fig. 1). The concentration temperature of $40^{\circ} \mathrm{C}$ is beneficial from the viewpoint of retention of compounds present in the fruits (28).

Already after $60 \mathrm{~min}$, the increase in dry matter content during concentration with enzymatic treatment was significantly higher than that achieved in the control sample (at $40{ }^{\circ} \mathrm{C}$ ), it amounted to $48.4 \%$ in the pretreatment with lipase and pectinase $\left(40{ }^{\circ} \mathrm{C}\right)$ and $48.2 \%$ during concentration in the presence of pectinase $\left(40^{\circ} \mathrm{C}\right)$.

As it is shown in Fig. 1a, the increase in dry matter content was similar in both procedures specified above. For instance, after $120 \mathrm{~min}$, dry matter content was $22.3 \%$ (by mass) when the fruits were pretreated with lipase and pectinase at $40{ }^{\circ} \mathrm{C}$, and $23.3 \%$ (by mass) during concentration with pectinase at $40{ }^{\circ} \mathrm{C}$. ANOVA confirms the lack of statistically significant differences $(p<0.05)$ in dry matter content between the studied procedures after 30,60, 90 and $120 \mathrm{~min}$ of concentration. However, even though the final dry matter content was similar after both treatments, some differences were observed in the mass transfer process (Figs. 1b and c).

The process conducted in the presence of pectinolytic enzymes was characterized by a greater water loss to hypertonic solution (Fig. 1b). For instance, gooseberry fruits concentrated for $90 \mathrm{~min}$ at $40{ }^{\circ} \mathrm{C}$ were found to lose twice as much water (about $2.0 \mathrm{~g}$ of $\mathrm{H}_{2} \mathrm{O}$ per $\mathrm{g}$ of initial dry matter) as those pretreated by immersion in the water bath with the addition of lipolytic and pectinolytic enzymes (about $1.0 \mathrm{~g}$ of $\mathrm{H}_{2} \mathrm{O}$ per $\mathrm{g}$ of initial dry matter). On the other hand, solid gain during concentration at $40{ }^{\circ} \mathrm{C}$ with pectinase was the most intensive during the first $60 \mathrm{~min}$ (an increase of process time from 30 to $60 \mathrm{~min}$ led to a threefold rise in the rate of solid gain), but after this time further solid gain was poor. Concentration conducted in the presence of pectinase was found to have an adverse effect on the fruits, i.e. it caused excessive hydrolysis of pectins leading to undesirable softening of the fruits.

There are limited data in the literature concerning the presence of enzymatic preparations during osmotic dehydration (28). Therefore, the proposed method may constitute an interesting alternative to non-thermal pretreatment in osmotic dehydration of gooseberry fruits. Excessive hydrolysis of pectins may probably be limited by the adjustment of the amount of enzymes and process parameters.

A different pattern of mass transfer was observed during osmotic concentration of gooseberry fruits pretreated with enzymatic preparations. After $30 \mathrm{~min}$, the water loss ( $0.56 \mathrm{~g}$ of $\mathrm{H}_{2} \mathrm{O}$ per $\mathrm{g}$ of initial dry matter) was similar to that obtained after $120 \mathrm{~min}$ for fruits not subjected to any additional treatment $\left(0.54 \mathrm{~g}\right.$ of $\mathrm{H}_{2} \mathrm{O}$ per $\mathrm{g}$ of initial dry matter). When the process time was increased from 60 to $120 \mathrm{~min}$, water loss in the fruits pretreated at $40{ }^{\circ} \mathrm{C}$ with enzymatic preparation rose by $0.72 \mathrm{~g}$ of $\mathrm{H}_{2} \mathrm{O}$ per $\mathrm{g}$ of initial dry matter. Solid gain in the fruits prepared at $40{ }^{\circ} \mathrm{C}$ with lipase and pectinase was almost twice as high after 120 min of concentration $(0.65 \mathrm{~g}$ of dry matter per $\mathrm{g}$ of initial dry matter) as that during concentration at $40{ }^{\circ} \mathrm{C}$ with pectinase $(0.36 \mathrm{~g}$ of dry matter per $\mathrm{g}$ of initial dry matter).
Enzymatic pretreatment did little damage to the epidermal layer of gooseberry fruits. Thus, we suppose that the better preserved structure of the fruits (Fig. 2 shows larger intercellular spaces compared to the material concentrated in the presence of pectinase) allowed for a greater penetration of the osmoactive substance.
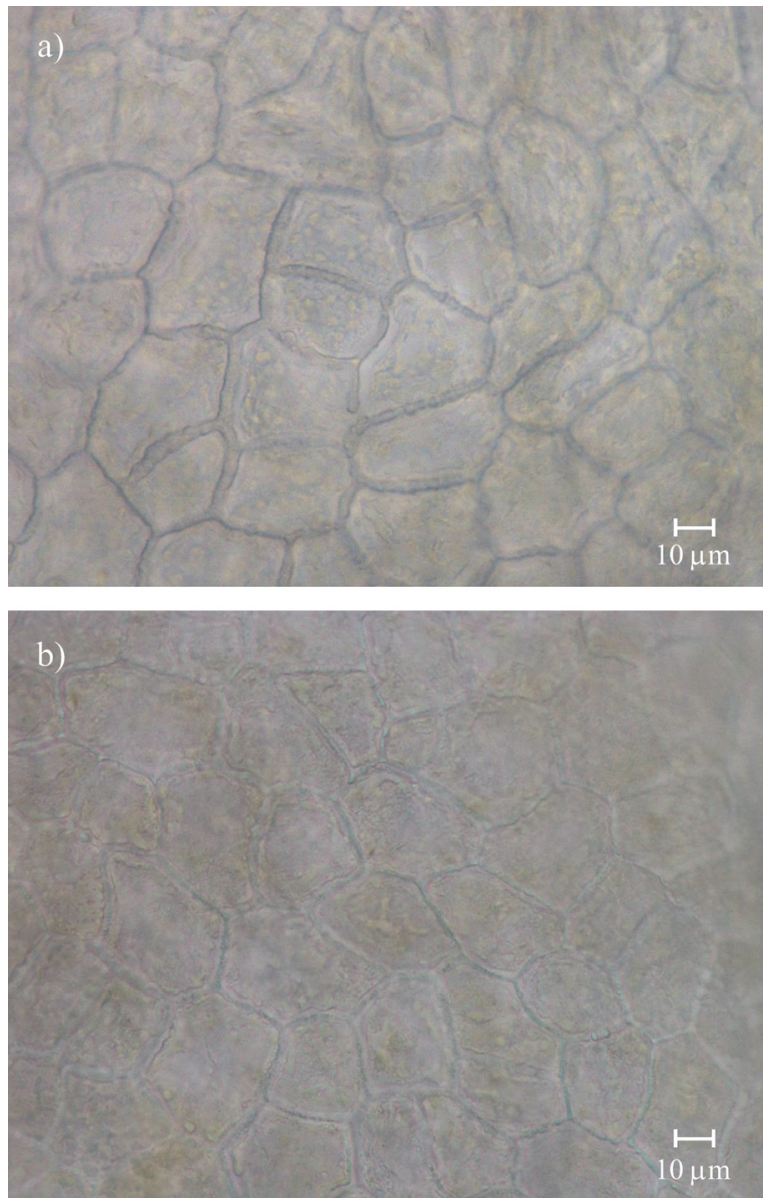

Fig. 2. Microscopic images of gooseberry skin from: a) fruits pretreated by immersion in a water bath containing lipase and pectinase and concentrated at $40{ }^{\circ} \mathrm{C}$, and b) fruits dehydrated in the presence of pectinolytic enzymes without pretreatment

\section{Total phenolic content}

The initial total phenolic content in gooseberry fruits was $(1347 \pm 47) \mathrm{mg}$ per $100 \mathrm{~g}$ of $\mathrm{dm}$, which corresponds to

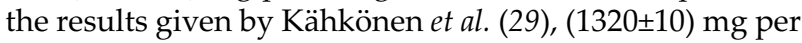
$100 \mathrm{~g}$ of $\mathrm{dm}$, and by Pantelidis et al. (30), (1321 \pm 10$) \mathrm{mg}$ per $100 \mathrm{~g}$ of $\mathrm{dm}$. The experiments reported in this study (Fig. 3) show that osmotic concentration conditions significantly influence the retention of phenolic compounds. Among the four temperatures used, the highest total polyphenol content was noted in fruits concentrated at $40{ }^{\circ} \mathrm{C}$ (retention of $93.2 \%$ as compared to the initial material after $240 \mathrm{~min}$ of concentration). After $120 \mathrm{~min}$ of concentration at 50 and $60{ }^{\circ} \mathrm{C}$, the decrease in total polyphenols was 11.9 and $15.6 \%$, respectively, as compared to the control sample. At $70{ }^{\circ} \mathrm{C}$, the fruits had the lowest total phenolic content (retention of $70.2 \%$ after $240 \mathrm{~min}$ ). Stojanovic and Silva (31) reported that following $3 \mathrm{~h}$ of osmotic concen- 


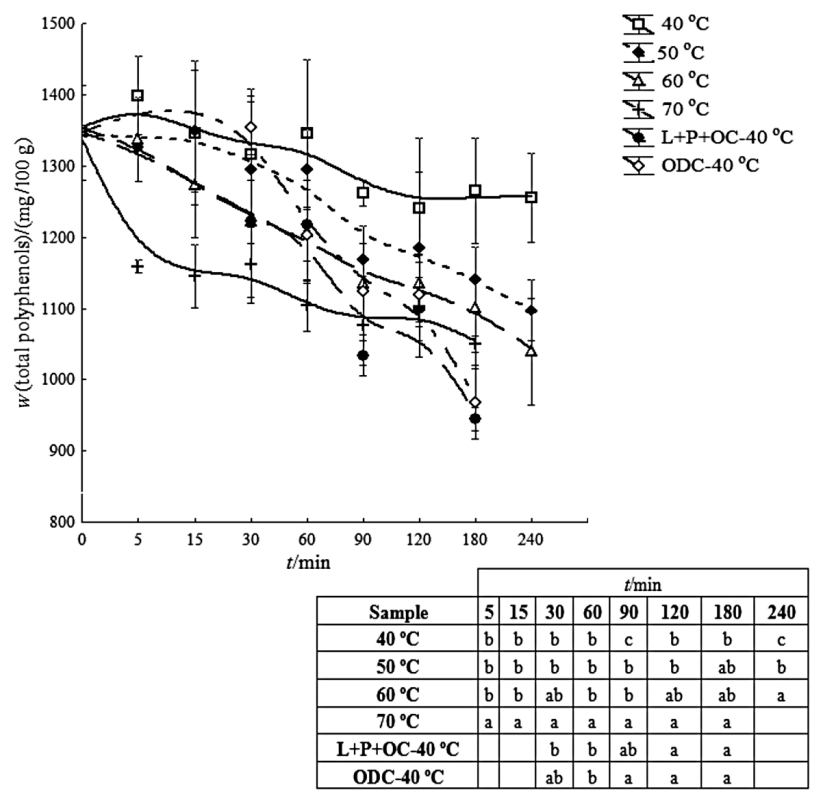

Fig. 3. Changes in total polyphenols during osmotic concentration of gooseberry fruits at 40,50,60 and $70{ }^{\circ} \mathrm{C}$, pretreated by immersion in water bath containing lipase or pectinase $(\mathrm{L}+\mathrm{P}+$ OC $-40{ }^{\circ} \mathrm{C}$ ) or concentrated in the presence of pectinolytic enzymes without pretreatment (ODP $\left.-40{ }^{\circ} \mathrm{C}\right)$. In table: the same letter for a given process time means no significant differences (95\% confidence level)

tration of rabbiteye blueberries (Vaccinium ashei) at $21^{\circ} \mathrm{C}$, total polyphenol loss was $20 \%$. In turn, raspberry fruits concentrated at $70{ }^{\circ} \mathrm{C}$ contained $22.0 \%$ less total polyphenols than those concentrated at $30^{\circ} \mathrm{C}(32)$. Phenolic content in fruits is particularly important due to the fact that these compounds reveal antioxidant properties and play a significant role in the prevention of diseases of civilization (33).

In experiments with enzymatic preparations, either in the presence of pectinolitic enzymes or in pretreatment with lipase and pectinase, the content of phenolic compounds systematically decreased with time (Fig. 3). Total polyphenol retention after $60 \mathrm{~min}$ in both procedures was by about $10 \%$ higher than in fruits concentrated at $70{ }^{\circ} \mathrm{C}$. After $120 \mathrm{~min}$, the retention values were similar. In the enzymatic pretreatment at $40^{\circ} \mathrm{C}$, the amount of polyphenols migrating to the syrup (Fig. 4) was similar to that at $60^{\circ} \mathrm{C}$ (in the treatment with pectinase at $40^{\circ} \mathrm{C}$ there was no significant difference), and considerably smaller than at 70 ${ }^{\circ} \mathrm{C}$. The amount of polyphenolic compounds in the solution following concentration was closely related to the parameters of the process. The greatest amount of total polyphenols in the syrup following osmotic concentration was observed at $70^{\circ} \mathrm{C}$ after $180 \mathrm{~min}$ (111.1 mg per $100 \mathrm{~g}$ of initial dry matter). The literature data indicate that high temperatures make the cell membrane lose its selective transport capacity and thus valuable nutrients are leached into the solution surrounding the fruits $(19,34)$.

A balance of total polyphenol content in the fruits and syrup prior to and following dehydration (Fig. 5) shows that the main cause of polyphenol loss in the fruits is migration to the hypertonic (sucrose) solution. Losses attributable to degradation amount to only a few percent.

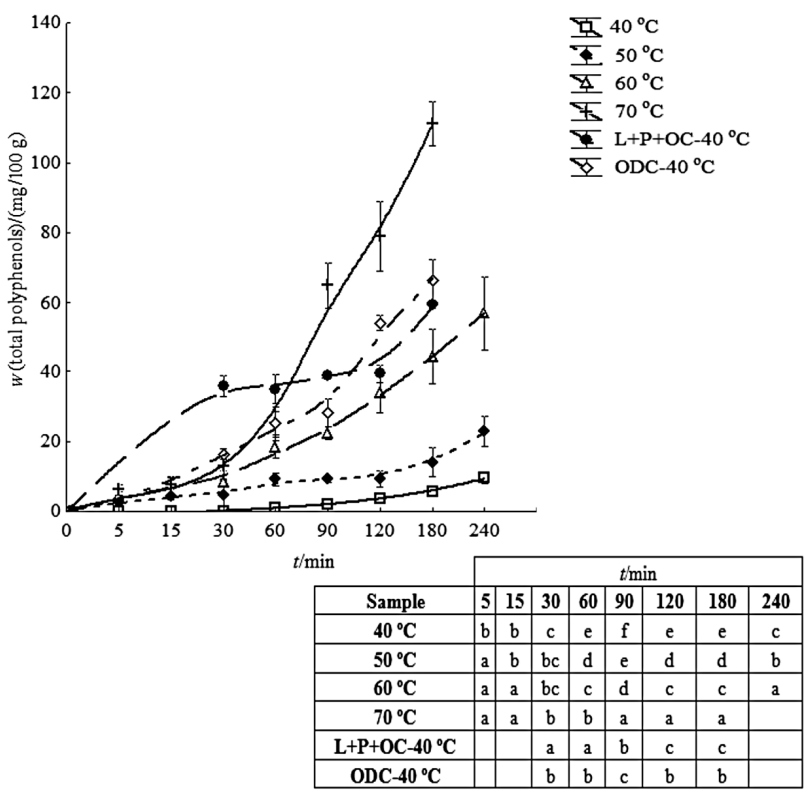

Fig. 4. Changes in total phenolic content in hypertonic solution during osmotic concentration of gooseberry fruits at 40,50, 60 and $70{ }^{\circ} \mathrm{C}$, pretreated by immersion in a water bath containing lipase or pectinase $\left(\mathrm{L}+\mathrm{P}+\mathrm{OC}-40^{\circ} \mathrm{C}\right)$ or concentrated in the presence of pectinolytic enzymes without pretreatment (ODC -40 ${ }^{\circ} \mathrm{C}$ ). In table: the same letter for a given process time means no significant differences ( $95 \%$ confidence level)

\section{Organic acid content}

The separation of organic acids in gooseberry fruits using HPLC technique is shown in Fig. 6. Three organic acids were identified in gooseberry fruits: malic (2689.9 $70.0)$, shikimic (1142.4 \pm 54.4$)$ and citric acid $(1254.7 \pm 19.8) \mathrm{mg}$ per $100 \mathrm{~g}$ of initial dry matter. These compounds typically occur in gooseberry fruits, which is confirmed by previous research (4).

During osmotic concentration of gooseberry fruits at different temperatures, changes in organic acid mass fraction were observed (Table 1). The retention of these compounds was high and remained at a level of $80-90 \%$. For instance, after $2 \mathrm{~h}$ of concentration at 50 and $60{ }^{\circ} \mathrm{C}, 88.3$ and $81.4 \%$ of initial malic acid mass fraction was retained, respectively. After $30 \mathrm{~min}$ of concentration at $40{ }^{\circ} \mathrm{C}$, its mass fraction was the highest relative to the initial sample $(93.0 \%)$, while an increase of process time to $120 \mathrm{~min}$ caused a drop of $18.5 \%$.

The mass fraction of shikimic acid in gooseberries osmotically concentrated at $70{ }^{\circ} \mathrm{C}$ decreased by $21.4 \%$ after $120 \mathrm{~min}$. In fruits concentrated at $60^{\circ} \mathrm{C}$, the content of this acid was in the range of 1112.3 to $1063.8 \mathrm{mg}$ per $100 \mathrm{~g}$ of initial dry matter. In the case of citric acid, the quantitative changes observed were small. After 60 min of concentration at $70{ }^{\circ} \mathrm{C}$, the retention of this compound was $93.1 \%$, and at $40{ }^{\circ} \mathrm{C}$ it was $94.1 \%$ relative to fresh fruits.

Greater quantitative differences in organic acid content were recorded in experiments with the use of enzymatic preparations. The lowest retention was found of shikimic acid, which was $76.3 \%$ after 120 min of concentration following enzymatic pretreatment. The retention of this acid following concentration in the presence of pec- 

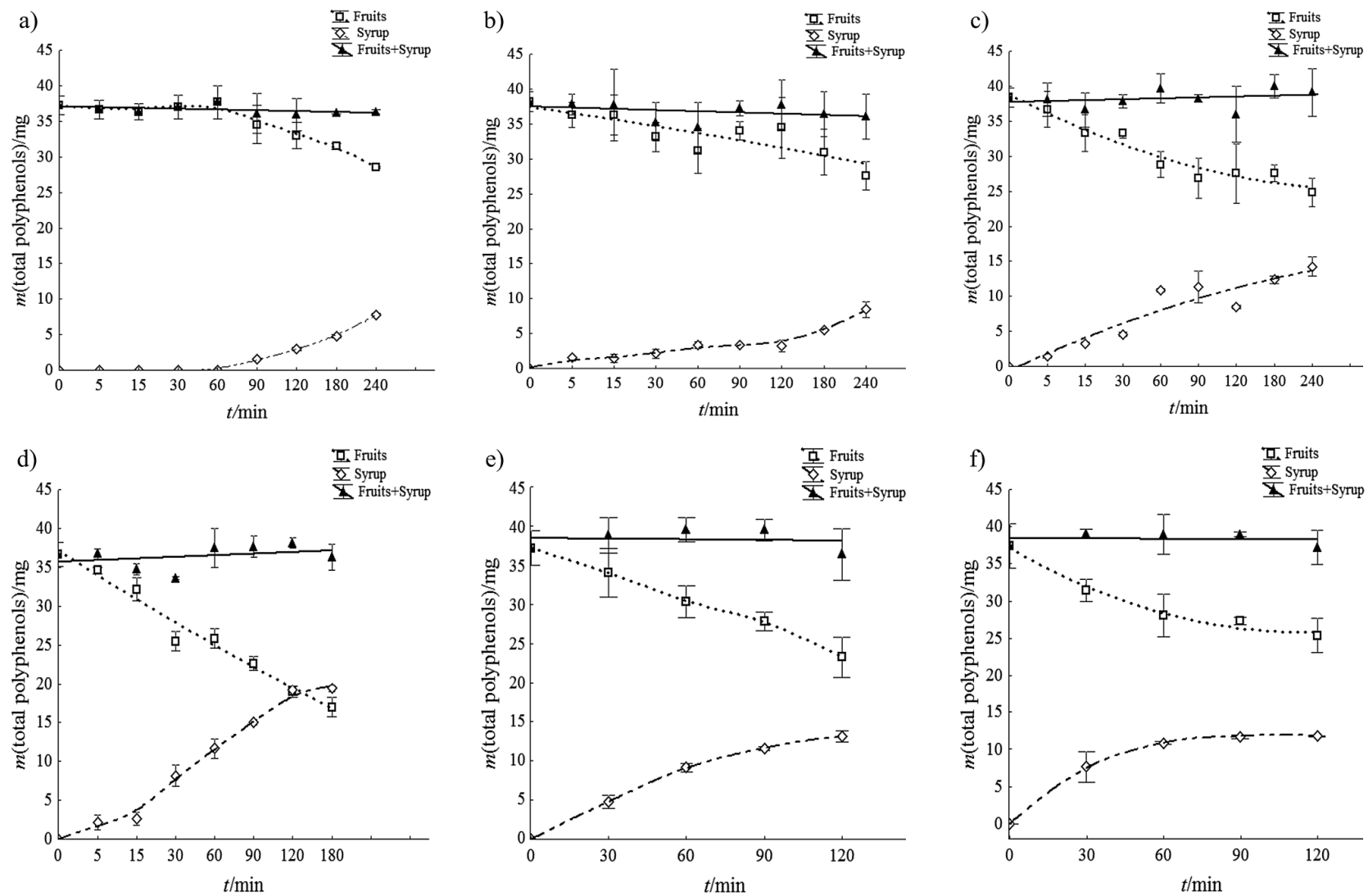

Fig. 5. Total polyphenols in the fruits and in the syrup during concentration at: a) 40 , b) 50, c) 60 , and d) $70{ }^{\circ} \mathrm{C}$, with e) enzymatic pretreatment $\left(\mathrm{OCP}-40^{\circ} \mathrm{C}\right)$ or $\left.\mathrm{f}\right)$ in the presence of pectinase $\left(\mathrm{L}+\mathrm{P}+\mathrm{OC}-40^{\circ} \mathrm{C}\right)$

Table 1 . Changes in organic acid content in osmotically concentrated fruits and syrups at 40,50,60 and $70{ }^{\circ} \mathrm{C}$, in the fruits subjected to concentration in the presence of pectinolytic enzymes $\left(\mathrm{OCP}-40^{\circ} \mathrm{C}\right)$, and in fruits pretreated with lipolytic and pectinolytic enzymes $\left(\mathrm{L}+\mathrm{P}+\mathrm{OC}-40^{\circ} \mathrm{C}\right)$

\begin{tabular}{|c|c|c|c|c|c|c|c|c|}
\hline \multirow{2}{*}{ Organic acid } & \multirow{2}{*}{ Control } & \multirow{2}{*}{$t / \min$} & \multicolumn{6}{|c|}{$w /(\mathrm{mg} / 100 \mathrm{~g})$} \\
\hline & & & $40^{\circ} \mathrm{C}$ & $50^{\circ} \mathrm{C}$ & $60^{\circ} \mathrm{C}$ & $70^{\circ} \mathrm{C}$ & $\mathrm{OCP}-40^{\circ} \mathrm{C}$ & $\mathrm{L}+\mathrm{P}+\mathrm{OC}-40^{\circ} \mathrm{C}$ \\
\hline \multicolumn{9}{|c|}{ Fruits } \\
\hline \multirow[t]{3}{*}{ malic acid } & $2689.9 \pm 70.0$ & 30 & $2502.0 \pm 62.0$ & $2456.4 \pm 48.7$ & $2410.8 \pm 70.5$ & $2541.3 \pm 63.2$ & $2244.9 \pm 66.4$ & $2333.6 \pm 40.2$ \\
\hline & & 60 & $2269.6 \pm 50.9$ & $2408.9 \pm 67.0$ & $2432.0 \pm 50.5$ & $2069.8 \pm 29.4$ & $2278.0 \pm 57.0$ & $2159.1 \pm 20.6$ \\
\hline & & 120 & $2191.6 \pm 72.7$ & $2376.5 \pm 40.4$ & $2189.0 \pm 51.2$ & $2115.0 \pm 30.7$ & $2086.4 \pm 70.2$ & $1905.1 \pm 63.1$ \\
\hline \multirow[t]{3}{*}{ shikimic acid } & $1142.4 \pm 54.4$ & 30 & $1197.1 \pm 39.1$ & $1130.1 \pm 24.4$ & $1112.3 \pm 22.1$ & $1118.0 \pm 17.1$ & $946.8 \pm 66.0$ & $940.8 \pm 75.6$ \\
\hline & & 60 & $1134.6 \pm 50.4$ & $1165.6 \pm 52.6$ & $1157.0 \pm 66.9$ & $1038.1 \pm 36.2$ & $919.8 \pm 5.5$ & $834.8 \pm 17.3$ \\
\hline & & 120 & $957.8 \pm 44.2$ & $1177.9 \pm 51.6$ & $1063.8 \pm 37.8$ & $998.5 \pm 30.5$ & $919.2 \pm 45.4$ & $871.8 \pm 45.5$ \\
\hline \multirow[t]{3}{*}{ citric acid } & $1254.7 \pm 19.8$ & 30 & $1218.4 \pm 15.1$ & $1259.2 \pm 73.9$ & $1152.2 \pm 64.2$ & $1187.8 \pm 35.6$ & $1102.1 \pm 17.5$ & $1103.0 \pm 33.3$ \\
\hline & & 60 & $1180.7 \pm 24.4$ & $1204.0 \pm 71.8$ & $1143.3 \pm 29.0$ & $1168.1 \pm 79.2$ & $1093.4 \pm 7.2$ & $1042.7 \pm 53.8$ \\
\hline & & 120 & $1128.5 \pm 9.4$ & $1204.0 \pm 30.9$ & $1029.0 \pm 24.1$ & $922.5 \pm 49.8$ & $1054.8 \pm 67.7$ & $1024.9 \pm 61.2$ \\
\hline \multicolumn{9}{|c|}{ Syrup } \\
\hline \multirow[t]{3}{*}{ malic acid } & $2689.9 \pm 70.0$ & 30 & $8.9 \pm 1.7$ & $17.4 \pm 1.7$ & $26.2 \pm 1.7$ & $71.1 \pm 2.1$ & $71.2 \pm 9.8$ & $32.6 \pm 2.0$ \\
\hline & & 60 & $26.5 \pm 1.2$ & $23.5 \pm 11.2$ & $32.2 \pm 1.3$ & $91.8 \pm 1.4$ & $192.8 \pm 14.8$ & $46.8 \pm 2.3$ \\
\hline & & 120 & $30.3 \pm 0.6$ & $46.8 \pm 6.2$ & $71.4 \pm 1.3$ & $127.5 \pm 3.4$ & $190.9 \pm 12.5$ & $97.7 \pm 3.6$ \\
\hline \multirow[t]{3}{*}{ shikimic acid } & $1142.4 \pm 54.4$ & 30 & $1.2 \pm 1.2$ & $14.4 \pm 1.8$ & $18.3 \pm 1.0$ & $42.1 \pm 1.5$ & $35.7 \pm 3.2$ & $18.5 \pm 1.9$ \\
\hline & & 60 & $1.6 \pm 0.1$ & $20.7 \pm 1.5$ & $24.3 \pm 0.0$ & $54.0 \pm 2.8$ & $109.1 \pm 7.5$ & $27.9 \pm 2.0$ \\
\hline & & 120 & $2.7 \pm 0.8$ & $30.5 \pm 4.3$ & $52.1 \pm 2.4$ & $73.4 \pm 5.0$ & $110.0 \pm 5.7$ & $58.0 \pm 3.4$ \\
\hline \multirow[t]{3}{*}{ citric acid } & $1254.7 \pm 19.8$ & 30 & $58.6 \pm 5.5$ & $62.2 \pm 1.0$ & $93.5 \pm 1.1$ & $122.0 \pm 5.9$ & $61.5 \pm 1.5$ & $100.3 \pm 7.3$ \\
\hline & & 60 & $80.1 \pm 5.7$ & $79.1 \pm 7.9$ & $105.7 \pm 12.0$ & $131.1 \pm 6.1$ & $93.0 \pm 7.0$ & $109.8 \pm 6.0$ \\
\hline & & 120 & $102.7 \pm 4.2$ & $82.1 \pm 7.2$ & $125.9 \pm 3.8$ & $147.0 \pm 12.6$ & $117.6 \pm 10.6$ & $127.6 \pm 5.1$ \\
\hline
\end{tabular}

Data expressed as milligrams of standard equivalents (malic, shikimic or citric acid) per $100 \mathrm{~g}$ of initial dry matter 


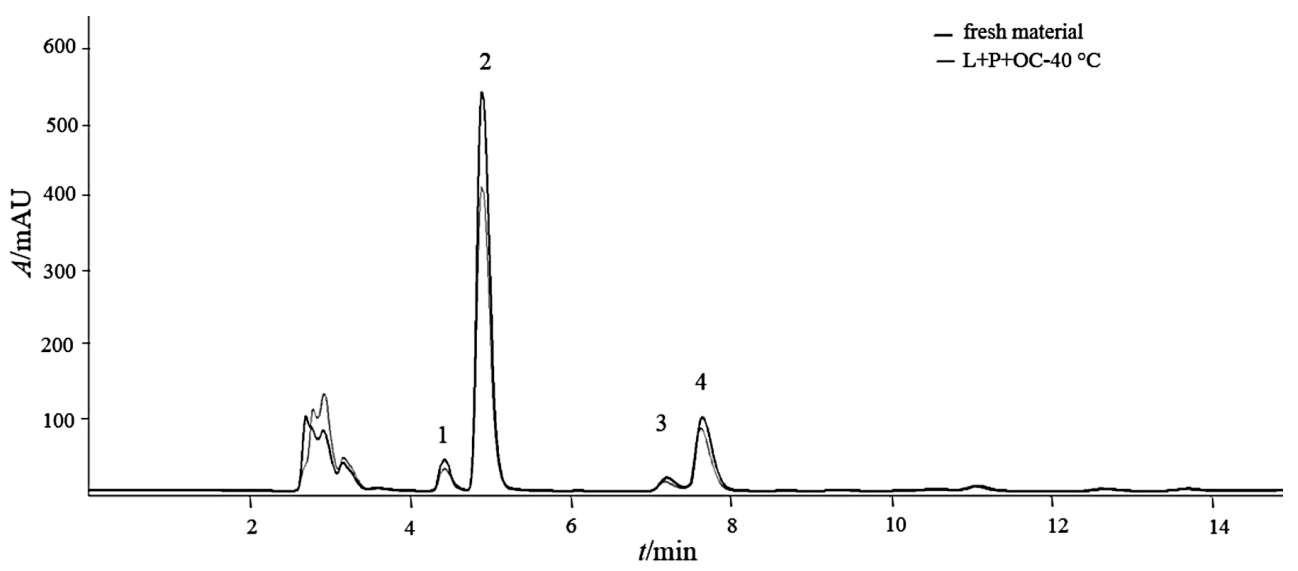

Fig. 6. HPLC chromatogram of gooseberry fruits with detection at $210 \mathrm{~nm}$. Compounds: $1=$ unidentified, $2=$ shikimic acid, $3=$ citric acid and $4=$ malic acid

tinase was $80.5 \%$. In the samples concentrated for $60 \mathrm{~min}$, losses of malic and citric acids in the pretreatment at $40{ }^{\circ} \mathrm{C}$ with lipase and pectinase were 19.7 and $16.9 \%$, respectively, while in the concentration at $40{ }^{\circ} \mathrm{C}$ with pectinase, they amounted to 15.3 and $12.9 \%$, respectively.

High temperature and enzymatic treatment led to greater water transfer from the fruits, and thus also to a higher loss of the organic acids, which dissolved in the solution. For instance, after $60 \mathrm{~min}$ of concentration at 70 ${ }^{\circ} \mathrm{C}$, malic acid content in the solution was $91.8 \mathrm{mg}$ per $100 \mathrm{~g}$ of initial dry matter, while at $40^{\circ} \mathrm{C}$ it was $26.5 \mathrm{mg}$ per $100 \mathrm{~g}$ of initial dry matter. After $120 \mathrm{~min}$ of osmotic concentration, the highest content of shikimic acid in the fruit syrup was found following the treatment in the presence of pectinolytic enzymes (110 mg per $100 \mathrm{~g}$ of initial dry matter), which was almost twice as high as in the case of concentration with enzymatic pretreatment (58.0 mg per $100 \mathrm{~g}$ of initial dry matter).

\section{Conclusions}

The parameters of the osmotic concentration process influence the rate of mass transfer and the composition of the final product. A higher temperature and a longer process time lead to higher dry matter content, water loss, and solid gain. The use of pectinolytic enzymes during osmotic concentration results in higher effectiveness of the process. Enzymatic treatment with lipase and pectinase before dehydration also increases solid gain during osmotic concentration. The parameters of the osmotic concentration have an influence on the retention of polyphenols and organic acids in gooseberry fruits; the lower processing temperature, the higher retention of phenolic compounds in the fruits. The main cause of the decrease of phenolics in gooseberry fruits under the tested conditions is migration to the hypertonic solution. The rate of polyphenol migration increases with temperature and process time. The following organic acids were identified in gooseberry fruits: malic, shikimic and citric acids. Their retention was at a level of $80-90 \%$ at the applied temperatures and during process times. The acid most vulnerable to the action of enzymes is shikimic acid. As regards practical aspects, enzymatic pretreatment with lipase and pectinase can reduce costs related to energy consumption (heating) during osmotic dehydration of fruit and enable better quality (more bioactive compounds) of the products.

\section{References}

1. K.E. Hummer, A. Dale, Horticulture of Ribes, Forest Pathol. 40 (2010) 251-263. http://dx.doi.org/10.1111/j.1439-0329.2010.00657.x

2. FAOSTAT: World Gooseberry Production in 2012 (http://faostat.fao.org/site/339/default.aspx).

3. S. Viljakainen, A. Visti, S. Laakso, Concentrations of organic acids and soluble sugars in juices from Nordic berries, Acta Agric. Scand. 52 (2002) 101-109. http://dx.doi.org/10.1080/090647102321089846

4. K. Stewart: Processing of Cranberry, Blueberry, Currant and Gooseberry. In: Processing Fruits: Science and Technology, D.M. Barrett, L. Somogyi, H. Ramsawamy (Eds.), CRC Press, Boca Raton, FL, USA (2005) pp. 563-584.

5. P. Flores, P. Hellín, J. Fenoll, Determination of organic acids in fruits and vegetables by liquid chromatography with tandem-mass spectrometry, Food Chem. 132 (2012) 1049-1054. http://dx.doi.org/10.1016/j.foodchem.2011.10.064

6. R.M. Marcé, M. Calull, R.M. Manchobas, F. Borrull, F.X. Rius, An optimized direct method for the determination of carboxylic acids in beverages by HPLC, Chromatographia, 29 (1990) 54-58.

http://dx.doi.org/10.1007/BF02261140

7. M.M. Theron, J.F.R. Lues: Nature and Composition of Organic Acids. In: Organic Acids and Food Preservation, CRC Press, Boca Raton, FL, USA (2011) pp. 29-38.

8. A.P. Oliveira, J.A. Pereira, P.B. Andrade, P. Valentăo, R.M. Seabra, B.M. Silva, Organic acids composition of Cydonia oblonga Miller leaf, Food Chem. 111 (2008) 393-399. http://dx.doi.org/10.1016/j.foodchem.2008.04.004

9. B.M. Keenan, S.R. Robinson, G.M. Bishop, Effects of carboxylic acids on the uptake of non-transfer in-bound iron by astrocytes, Neurochem. Int. 56 (2010) 843-849. http://dx.doi.org/10.1016/j.neuint.2010.03.009

10. R.A. Moyer, K.E. Hummer, C.E. Finn, B. Frei, R.E Wrolstad, Anthocyanins, phenolics, and antioxidant capacity in diverse small fruits: Vaccinium, Rubus, and Ribes, J. Agric. Food Chem. 50 (2002) 519-525. http://dx.doi.org/10.1021/jf011062r

11. S. Häkkinen, M. Heinonen, S. Kärenlampi, H. Mykkänen, J. Ruuskanen, R. Törrönen, Screening of selected favonoids and 
phenolic acids in 19 berries, Food Res. Int. 32 (1999) 345-353. http://dx.doi.org/10.1016/S0963-9969(99)00095-2

12. J. Borkowska, Fruits and vegetables as source of natural antioxidant, Przem. Ferm. Ow. Warz. 5 (2003) 11-12.

13. M.D.S. Pinto, Y.I. Kwon, E. Apostolidis, F.M. Lajolo, M.I. Genovese, K. Shetty, Evaluation of red currants (Ribes rubrum L.) red and green gooseberries (Ribes uva-crispa) for potential management of type 2 diabetes and hypertension using in vivo models, J. Food Biochem. 34 (2010) 639-660. doi: 10.1111/j.1745-4514.2009.00305.x

14. J. Krisch, L. Ördögh, L. Galgóczy, T. Papp, C. Vágvölgyi, Anticandidal effect of berry juices and extracts from Ribes species, Centr. Eur. J. Biol. 4 (2009) 86-89. http://dx.doi.org/10.2478/s11535-008-0056-z

15. D. Torreggiani, G. Bertolo, Osmotic pre-treatments in fruit processing: Chemical, physical, and structural effects, J. Food Eng. 49 (2001) 247-253. http://dx.doi.org/10.1016/S0260-8774(00)00210-7

16. A.B. Nieto, S. Vicente, K. Hodara, M.A. Castro, S.M. Alzamora, Osmotic dehydration of apple: Influence of sugar and water activity on tissue structure, rheological properties and water mobility, J. Food Eng. 119 (2013) 104-114. http://dx.doi.org/10.1016/j.jfoodeng.2013.04.032

17. N.K. Rastogi, K.S.M.S. Raghavarao, Mass transfer during osmotic dehydration: Determination of moisture and soluble diffusion coefficients from concentration profiles, Food Bioprod. Process. 82 (2004) 44-48. http://dx.doi.org/10.1205/096030804322985308

18. S. Grabowski, M. Marcotte, D. Quan, A.R. Taherian, M.R. Zareifard, M. Poirier, T. Kudra, Kinetics and quality aspects of Canadian blueberries and cranberries dried by osmo-convective method, Drying Technol. 25 (2007) 367-374. http://dx.doi.org/10.1080/07373930601120563

19. P.P. Lewicki, A. Lenart: Osmotic Dehydration of Fruits and Vegetables. In: Handbook of Industrial Drying, A.S. Mujumdar (Ed.), CRC Press, Boca Raton, FL, USA (2006) pp. 665688.

20. S. Rodrigues, M.C.F. Gomes, M.I. Gallão, F.A.N. Fernandes, Effect of ultrasound-assisted osmotic dehydration on cell structure of sapotas, J. Sci. Food Agric. 89 (2009) 666-670. http://dx.doi.org/10.1002/jsfa.3498

21. A. Wiktor, M. Śledź, M. Nowacka, T. Chudoba, D. Witrowa-Rajchert, Pulsed electric field pretreatment for osmotic dehydration of apple tissue: Experimental and mathematical modeling studies, Drying Technol. 32 (2014) 408-417. http://dx.doi.org/10.1080/07373937.2013.834926

22. L.S. Badwaik, M. Choudhury, K.K. Dash, P.K. Borah, S.C Deka, Osmotic dehydration of bamboo shoots enhanced by centrifugal force and pulsed vacuum using salt as osmotic agent, J. Food Process. Preserv. 38 (2013) 1-9. http://dx.doi.org/10.1111/jfpp.12186

23. R.M. Bórquez, E.R. Canales, J.P. Redon, Osmotic dehydration of raspberries with vacuum pretreatment followed by microwave-vacuum drying, J. Food Eng. 99 (2010) 121-127. http://dx.doi.org/10.1016/j.jfoodeng.2010.02.006

24. M. Matuska, A. Lenart, N. Lazarides, On the use of edible coatings to monitor osmotic dehydration kinetics for minimal solids uptake, J. Food Eng. 72 (2006) 85-91. http://dx.doi.org/10.1016/j.jfoodeng.2004.11.023

25. V.L. Singleton, J.A. Rossi, Colorimetry of total phenolics with phosphomolybdic-phosphotungstic acid reagents, Am. J. Enol. Vitic. 16 (1965) 144-158.

26. A. Derossi, T.D. Pilli, C. Severini, M.J. McCarthy, Mass transfer during osmotic dehydration of apples, J. Food Eng. 6 (2008) 519-528. http://dx.doi.org/10.1016/j.jfoodeng.2007.11.007

27. P.P. Lewicki, R. Porzecka-Pawlak, Effect of osmotic dewatering on apple tissue structure, J. Food Eng. 66 (2005) 43-50. http://dx.doi.org/10.1016/j.jfoodeng.2004.02.032

28. A. Kucner, R. Klewicki, M. Sójka, The influence of selected osmotic dehydration and pretreatment parameters on dry matter and polyphenol content in highbush blueberry (Vaccinium corymbosum L.) fruits, Food Bioprocess Technol. 6 (2012) 2031-2047. http://dx.doi.org/10.1007/s11947-012-0997-0

29. M.P. Kähkönen, A.I. Hopia, M. Heinonen, Berry phenolics and their antioxidant activity, J. Agric. Food Chem. 49 (2001) 4076-4082. http://dx.doi.org/10.1021/jf010152t

30. G.E. Pantelidis, M. Vasilakakis, G.A. Manganaris, G. Diamantidis, Antioxidant capacity, phenol, anthocyanin and ascorbic acid contents in raspberries, blackberries, red currants, gooseberries and Cornelian cherries, Food Chem. 102 (2007) 777-783. http://dx.doi.org/10.1016/j.foodchem.2006.06.021

31. J. Stojanovic, J.L. Silva, Influence of osmotic concentration, continuous high frequency ultrasound and dehydration on antioxidants, colour and chemical properties of rabbiteye blueberries, Food Chem. 101 (2007) 898-906. http://dx.doi.org/10.1016/j.foodchem.2006.02.044

32. M.M. Novaković, S.M. Stevanović, S.Ž. Gorjanović, P.M. Jovanovic, V.V. Tešević, M.A. Janković, D.Ž. Sužnjević, Changes of hydrogen peroxide and radical-scavenging activity of raspberry during osmotic, convective, and freeze-drying, J. Food Sci. 76 (2011) 663-668. http://dx.doi.org/10.1111/j.1750-3841.2011.02144.x

33. S. Petti, C. Scully, Polyphenols, oral health and disease: A review, J. Dent. 37 (2009) 413-423. http://dx.doi.org/10.1016/j.jdent.2009.02.003

34. S.S. Sablani, S.M. Rahman, Effect of syrup concentration, temperature and sample geometry on equilibrium distribution coefficients during osmotic dehydration of mango, Food Res. Int. 36 (2003) 65-71. http://dx.doi.org/10.1016/S0963-9969(02)00109-6 